\title{
An Understanding of the Islamic Banking Industry from Customers' Perspective
}

\author{
Rebeka Sultana Chowdhury \\ Lecturer, Department of Business Administration, North East University Bangladesh, Telihaor, Sheikhghat, Sylhet-3100, BANGLADESH \\ E-mail for correspondence: rebekasc26@gmail.com
}

\begin{abstract}
During the last decade, conventional banks faced stiff competition from Islamic bank. The main purpose of the study is to find out the customers' perspective on Islamic banking in Bangladesh. The study was based on both primary and secondary data. For collecting primary data, a questionnaire survey was conducted among Islamic banks' customers. Selection of respondents was based on random sampling as well as the convenient sampling method. Customer opinions were measured by a 5-point Likert scale. Customers' perspectives have been measured with respect to various aspects (service quality, profit rate, service charge, internet banking, employee proficiency, etc.). Findings of the study reveal that the respondents think positively about almost all aspects of the Islamic bank.
\end{abstract}

Keywords: Islamic bank, Customer perspective, Bangladesh, Service quality, Banking sector JEL Classification Code: G21

\section{INTRODUCTION}

Islamic finance is one of the fastest growing sectors in the global financial industry. According to Wikipedia of Islamic banking and finance the term "Islamic banking" refers to a system of banking or banking activity that is consistent with Islamic law (Shariah) and guided by Islamic economy. A correct term for Islamic banking is shariah-compliant finance.The contemporary movement of Islamic finance has been based on the belief that "all forms of interest are Riba and hence prohibited". Also, Islamic law prohibits investing in businesses that are considered unlawful, or haraam (such as business activities that deal with alcohol or pork). Islamic banking is different from conventional banking. Interest is the feature that differentiates Islamic banks from traditional banks. Islamic banks provide interest- free products whereas non-Islamic banks provide interest- based products. Since interest is prohibited, Islamic banks must, therefore, find alternative ways compatible with the Sharia pillars for the various banking functions. Islamic banking introduces concepts such as Profit sharing (Mudharabah), safekeeping (Wadiah), Joint venture (Musharakah), cost plus Murabaha, and Leasing (Ijar), cash advances for the purchase of agricultural produce (Salam) and cashes advances for the manufacture of assets (istisna), etc. Most of the Islamic Banks operate on Bai- Murabaha, Bai
Muazzal, Bai- Salam, Istisna, Hire Purchase/ Leasing mode of Investment.

Islamic banking system is not a recent idea. It introduced a long time ago. Islami banks were basically emerged to fulfill the need of Muslims to use banking products and services in compliance with Islamic principles. The theoretical work to introduce Islamic banking began in 1940.But the experimental work taking place in1960. The Mit-Ghamr Islamic Savings Bank (MGISB) started in Egypt in 1963, which was the first Islami Bank in the world. In earlier days, the tendency of customers to accept the Islamic banking system was modest but day by day it increased. With 15 per cent -20 per cent growth annually, Islamic banking was expanded almost all most important parts of the world. Not only Muslims but also Non-Muslim customers around the world are interested in Islamic banking. Now Islamic financial institutions are operating in more than 105 countries. According to World Islamic Banking Competitiveness Report (2014-15), Islamic banking assets are set to touch US\$753billion in 2014. Expect a growth of 19\% through 2014-19, with total assets reaching US\$1.8trillion. By 2019, participation banking profit pool would reach US\$36.9billion. Sharia-compliant banking grew at an annual rate of $17.6 \%$ between 2009 and 2013, which was 1.9 times higher than conventional banking. 
The globally-booming Islamic banking is making strides and gaining popularity in Bangladesh. Bangladesh is one of the major countries among the others who are witnessing significant growth in Islami banking sector. In 1983, the first Islamic Bank named Islami Bank Bangladesh Limited established in Bangladesh, which was the first Islami bank in South East Asia region. Since its inception, Islami banking industry has continued to show steady growth. Today, various national and international commercial banks in Bangladesh are offering Islami banking services through Islami banking branches and window. According to Bangladesh Bank's statistics, in the financial year 2015, out of 56 banks, eight private commercial banks operated as full-fledged Islami banks and 16 conventional banks including three foreign commercial banks are involved in Islami banking through Islami banking branches and windows.

Over the last decade, Bangladesh economy secured an average of $6.2 \%$ growth rate well above the global economic growth. The banking sector is a major sector on Bangladesh economy and has achieved extraordinary growth and intense competition during the last decade. According to Bangladesh Bank statistics published in the annual report (2014-2015), banking sector achieves a growth rate of $8.3 \%$ in the financial year 2014 and $9.8 \%$ in the economic year 2015. The contribution of Islamic bank in the growth of banking sector is huge. Bangladesh Bank states that, total deposits of the Islamic banks and Islamic banking branches of the conventional banks stood at Taka 1417.3 billion at the end of December 2014 which accounted for 20.3 percent of whole deposits. Entire credit of the Islamic banks and the Islamic banking branches of the conventional banks stood at Taka 1195.4 billion at the end of December 2014 which accounted for 22.2 percent of total credit of the banking system of the country. According to Bangladesh Bank, the growth of deposits is more in Islamic banks than in conventional banks. In 2013, Islamic banks' deposit growth was 25.83 percent compared to 20.58 percent in non-Islamic banks. At the end of July-September 2014 quarter, deposits, investments and surplus liquidity of Islamic banking industry grew by 3.58 percent, 2.90 percent, and 26.24 percent respectively. Islami Bank Bangladesh Limited, the first Islamic bank in Bangladesh is leading in term of net profit since the last decade.

Banks play a significant role in a country's economy, and customers are the key factors for ensuring banks success. The current highly competitive environment and the increasing complication of banks make it very tricky to gain customer satisfaction and reliability. This study has been conducted to find out the present position of Islamic banking in the sight of the customer.

\section{Objectives}

The aims of the research are the following-

- To explore the perception of the consumer regarding the Islamic Banking.

- To check the awareness level of the people about various Islamic bank products/services.

- To evaluate the current practice and performances of the Islamic banks in Bangladesh

- To recommend actions that may be necessary to solve the problems faced by customers.

\section{LITERATURE REVIEW}

Several studies underlined the need to understand the customer's perspective regarding Islamic bank during the last decade. Customer satisfaction is directly related to customer's loyalty, and an increase in satisfaction also increases the long-term commitment of customer. The customers' satisfaction has been based upon individual and overall transactions executed by any client, customer's perceived service quality and also on the assurance of using Islamic Shari'ah principles (Hassan et al., 2012).

Yousuf et al. (2014) conducted research on Islamic Banking Scenario of Bangladesh. According to their findings Convenience of opening accounts or the quality of the services offered does not have much impact on the consumer's decision of choosing an Islamic banking system. But for the Shariah-based activities of the Islamic banks, their reliable commitment to the customer and their behaviour encourage the Muslim to be attracted by the Islamic banks. Bashir (2013) indicates that awareness is positively and significant associated with customer satisfaction, service quality, and product quality in Brunei Darussalam's Islamic banking.

The proliferation of the Islamic banking institutions throughout the world, as well as the entry of a huge number of conventional banks into this market, is all undeniable evidence of the growth of the Islamic banking. (Nadia et al., 2014). In today's highly competitive corporate environment, quality of services is an essential element for enhancing customer satisfaction and customer loyalty. Khan \& Fasih (2014) states that service quality and all its dimensions such as tangibles, reliability, assurance and empathy have significant and positive association with satisfaction and loyalty of customers towards their respective financial service providing organizations.

Hassan et al. (2012) assures the enormous significant relationship between customer's loyalty and customer's perception, which is based on the religious and interest- 
free factor of Islamic banks. They also find out that switching cost and trust and commitment of customers have a greater impact on the consumer's loyalty. A study conducted by Naser et al. (2013) on Kuwait Finance House (KFH) states that the respondents were attached a relatively high degree of agreement with the reason that they deal with both commercial and Islamic banks to diversify their investment. They also showed that the customers are dealing with Kuwait Finance House (KFH) not for the profitability reasons but for the confidentiality, bank credibility, confidence in the Shariah Supervisory Committee and belief in the bank's management. According to Naser and Mountinho (1997), Islamic banks are facing competition not only from other Islamic banks but also from conventional banks; bearing in mind that many usual banks are currently providing Islamic financial services through "Islamic windows".

Khan et al. (2007) reveal that majority of the current Islamic bank customers in Bangladesh have a previous banking relationship with traditional banks. And Services offered by Islamic banks such as ATM services, SWIFT for international funds transfer, local documentary Bill purchased, foreign documentary Bill purchased, letter of credit, locker service are very similar to the ones offered by the conventional banks (excluding implications of interest, if any at all). Islamic banking is needed consciousness program among people in Pakistan because people are not aware of it. So a comprehensive awareness campaign is required for the promotion of Islamic banking (Khan\& Ahmad, 2013).

Khattak \& Rehman (2010) states that regarding the Islamic banking selection criteria most of the customers have adopted Islamic banking due to the religious reasons, but there are some other factors that motivate the customers for the adoption of the Islamic banking system such as, bank efficiency in the transaction, their confidentiality to its clients, its working hours etc. From the aspects of Islamic banks, it's proved that the customers are encouraged because of interest-free loan, Islamic teaching, and shariah, awareness of Islam, and religious up bring in the country (Begum, 2014). It is found by Akhtar et al. (2011) that customer satisfaction is positively related to service quality in Islamic banking which comprised of standardizing variables being followed by Islamic banks. Abduh et al. (2012) confirm that the better the performance of the Islamic bank services, particularly in the staff-customer relationship, costs and charges applied, and bank accessibility, the lower the likelihood of the customers to switch from those banks in Indonesia.

\section{RESEARCH METHOD}

To achieve the objectives of the study both primary and secondary data has been used. But the study is mainly based on primary data. Primary data was collected through a well-structured questionnaire using personally interviewing the customers of Islamic banks. The survey comprises of two sections. The first one is related to the personal information of the respondents including their age, gender, marital status, educational qualification, profession, and income level. The second section includes the questions relevant to several factors associated with customer perception about Islamic banks. Customer trust, satisfaction, and opinions are measured by a 5-point Likert scale ranging from $1=$ strongly disagree to $5=$ strongly agree. The population of the study comprises of all the existing full-fledged Islamic bank customers in Bangladesh. This sample selection is a limitation of this study. A wider geographic distribution of our sample respondents would be an ideal one but due to various constraints, we had to impound ourselves to Sylhet City only. Selection of respondents was based on random sampling as well as convenient sampling method. A total of 150 questionnaires were distributed, of which 120 questionnaires have been received as completely filled-up.

The survey was conducted on 120 persons, 49 of them were the customers of Islami Bank Bangladesh Ltd, 20 of EXIM Bank Bangladesh Ltd, 17 of Al-Arafah Islami Bank Ltd, 13 of Shahjalal Islami Bank Ltd, 11 of Social Islami Bank Ltd, and 10 of First Security Islami Bank Ltd.

Secondary data have been collected from various sources like journal articles, annual reports of different banks, books, and different websites. For the purpose of our study, for analyzing the data, we choose the descriptive statistics.

\section{FINDINGS AND ANALYSIS}

\section{Respondents Background Information}

The questionnaire's first part was designed to gather data about the participant's background. Table 1 represents background statistics about the participants found from the study. As shown in the table, the majority of the respondents are male $(67.5 \%)$, and rest $(32.5 \%)$ are female. Among 120 respondents, 54.2\% are married, and $45.8 \%$ are unmarried. Age group of the sample indicates that $43.3 \%$ are between 21 and 30 years of age whereas $29.2 \%$ are between 31 and 40 years of age. Most of the customers (40.8\%) of Islamic bank are Graduate, $27.5 \%$ respondents have a higher secondary degree, and $23.3 \%$ are post-graduate. Customers are having an educational qualification 
Secondary degree and below Secondary level represents $6.7 \%$ and $1.7 \%$ respectively.

Table 1: Respondents' Background

\begin{tabular}{|c|c|c|c|}
\hline \multicolumn{2}{|c|}{ Variables } & Frequency & Percentage \\
\hline \multirow[t]{3}{*}{ Gender } & Male & 81 & 67.5 \\
\hline & Female & 39 & 32.5 \\
\hline & Total & 120 & 100 \\
\hline \multirow{3}{*}{$\begin{array}{l}\text { Marital } \\
\text { Status }\end{array}$} & Married & 65 & 54.2 \\
\hline & Unmarried & 55 & 45.8 \\
\hline & Total & 120 & 100 \\
\hline \multirow[t]{6}{*}{ Age group } & Up to 20 Years & 17 & 14.2 \\
\hline & 21-30 Years & 52 & 43.3 \\
\hline & $31-40$ Years & 35 & 29.2 \\
\hline & 41-50 Years & 12 & 10.0 \\
\hline & Above 50 Years & 04 & 3.3 \\
\hline & Total & 120 & 100 \\
\hline \multirow{6}{*}{$\begin{array}{l}\text { Educational } \\
\text { qualification }\end{array}$} & Below SSC & 02 & 1.7 \\
\hline & SSC & 08 & 6.7 \\
\hline & HSC & 33 & 27.5 \\
\hline & Graduate & 49 & 40.8 \\
\hline & Post Graduate & 28 & 23.3 \\
\hline & Total & 120 & 100 \\
\hline \multirow[t]{5}{*}{ Profession } & Service & 31 & 25.8 \\
\hline & Business & 39 & 32.5 \\
\hline & Student & 35 & 29.2 \\
\hline & Homemaker & 15 & 12.5 \\
\hline & Total & 120 & 100 \\
\hline \multirow[t]{6}{*}{ Income level } & Up to tk 25000 & 56 & 46.7 \\
\hline & $25001-50000$ & 46 & 38.3 \\
\hline & $50001-75000$ & 11 & 9.2 \\
\hline & $75001-100000$ & 06 & 5.0 \\
\hline & $\begin{array}{ll}\text { More } & \text { than } \\
100000 & \\
\end{array}$ & 01 & 0.8 \\
\hline & Total & 120 & 100 \\
\hline \multirow{5}{*}{$\begin{array}{l}\text { Bank } \\
\text { Account } \\
\text { Type }\end{array}$} & $\begin{array}{l}\text { Current } \\
\text { Account }\end{array}$ & 39 & 32.5 \\
\hline & $\begin{array}{l}\text { Savings } \\
\text { Account }\end{array}$ & 60 & 50 \\
\hline & Fixed Deposit & 16 & 13.3 \\
\hline & Scheme Deposit & 05 & 4.2 \\
\hline & Total & 120 & 100 \\
\hline \multirow{6}{*}{$\begin{array}{l}\text { Number of } \\
\text { years } \\
\text { dealing with } \\
\text { an Islamic } \\
\text { bank }\end{array}$} & Less than 1 year & 32 & 26.7 \\
\hline & $1-5$ years & 62 & 51.7 \\
\hline & $6-10$ years & 23 & 19.2 \\
\hline & $11-15$ years & 01 & 0.8 \\
\hline & $\begin{array}{l}\text { More than } 15 \\
\text { years }\end{array}$ & 02 & 1.6 \\
\hline & Total & 120 & 100 \\
\hline
\end{tabular}

Source: Calculated from primary data

It reveals from the survey that $32.5 \%$ customers are engaged in business, $25.8 \%$ respondents are service holder and $29.2 \%$ are students. A minor portion of the female customers $(12.5 \%)$ is the homemaker. A key segment of the customers (46.7\%) of Islamic bank earns below BDT25000, 38.3\% of the participants earned between BDT25001-50000. A small section of the respondents $9.2 \%, 5 \%$ and $0.8 \%$ belongs to the income level BDT50001-75000, BDT75001-100000 and more than BDT100000 respectively.

Half of the participants (50\%) have savings account in the Islamic bank. $32.5 \%$ maintain a current account, $13.3 \%$ open fixed deposit account and the rest $4.2 \%$ have different scheme deposit with the Islamic bank. The study reveals that majority $(51.7 \%)$ of the customers deal with Islamic bank for $1-5$ years, $19.2 \%$ have a relation for 6-10 years. A small portion $(0.8 \%)$ has Islamic bank account for $11-15$ years and rest $1.6 \%$ have the relation for more than 15 years.

\section{Customers Bank Selection Perception}

Table 2 presents the factors that influence the customers to open an account in the Islamic bank. The majority of the customers $(33.3 \%)$ told that their family members persuade them to open an account in the Islamic bank. $25.8 \%$ agree that they were influenced by their friends, and $17.5 \%$ were convinced by their relatives. The rest of the respondents were influenced by the bank or employee advertising (15\%), colleagues (6.7\%). Small portions $(1.7 \%)$ of the customers are self-motivated.

Table 2: Influential Factors to open account in Islamic Bank

\begin{tabular}{|l|c|c|}
\hline Factor & Frequency & Percent \\
\hline Family & 40 & 33.3 \\
\hline Friends & 31 & 25.8 \\
\hline Relatives & 21 & 17.5 \\
\hline Colleagues & 08 & 6.7 \\
\hline Bank/Employee advertising & 18 & 15 \\
\hline None & 02 & 1.7 \\
\hline Total & 120 & 100 \\
\hline
\end{tabular}

Source: Calculated from primary data

The respondents were asked to identify the level of their agreement with some possible reasons that inspire them to deal with an Islamic bank.

Table 3 summarizes the reasons for choosing Islamic bank by the customer. $35.8 \%$ respondents told that they maintained an account with Islamic bank because it operates under Islamic rules and regulation. 10.8\% continue an account with Islamic bank because Islamic bank provides a higher rate of profit than conventional bank, and 24.2\% maintained an account for both religious and profitability reasons. 13.4\% have Islamic bank account because they provide fast and friendly services. The participants attached a relatively small level of conformity with reasons such as Location of branches $(10.8 \%)$, Wide range of facilities offered by the bank $(4.2 \%)$ and Bank reputation $(0.8 \%)$. 
Table 3: Reason for Choosing Islamic Bank

\begin{tabular}{|l|c|c|}
\hline Reason & Frequency & Percent \\
\hline Religious reasons & 43 & 35.8 \\
\hline Higher profit & 13 & 10.8 \\
\hline Both religious and profitability Reasons & 29 & 24.2 \\
\hline Fast \& Friendly services & 16 & 13.4 \\
\hline Location of branches & 13 & 10.8 \\
\hline Wide range of facilities offered by the bank & 05 & 4.2 \\
\hline Bank reputation & 01 & 0.8 \\
\hline Total & 120 & 100 \\
\hline
\end{tabular}

Source: Calculated from primary data

It is a common practice by many customers who maintain an account with both conventional and Islamic banking systems. In this study, 50.8\% respondents have only Islamic bank account, and $49.2 \%$ have the deal with both Islamic bank and traditional bank. The respondents in the survey have been provided with a list of reasons in the questionnaire that might express why they dealt with both non-Islamic and Islamic banks and were asked to provide their reasons. The feedback has been summarized in Table 5. From the table, it shows that higher numbers of respondents agree with the reason that they deal with both banking systems because Islamic bank give limited banking facilities to their client. Two group of the respondent (22\%) provide the reason that they can diversify their investment and Islamic bank offered little investment opportunity to their client so that they deal with the alternative banking system. 18.7\% provide the network reason behind their dealing. And only $5.1 \%$ told that they have to maintain an account with the conventional bank because of their salary account.

Table 4: Selection of Banking System by Respondents

\begin{tabular}{|l|c|c|}
\hline \multicolumn{1}{|c|}{ Banking System } & Frequency & Percent \\
\hline Only Islamic Bank & 61 & 50.8 \\
\hline Both Islamic bank and conventional bank & 59 & 49.2 \\
\hline Total & 120 & 100 \\
\hline
\end{tabular}

Source: Calculated from primary data

Table 5: Reasons behind dealing with both Islamic and conventional banking system

\begin{tabular}{|l|c|c|}
\hline Reason & Frequency & Percent \\
\hline $\begin{array}{l}\text { Limited banking facilities offered by } \\
\text { Islamic banking system }\end{array}$ & 19 & 32.2 \\
\hline Investment diversification opportunity & 13 & 22 \\
\hline Network reason & 11 & 18.7 \\
\hline $\begin{array}{l}\text { Low investment opportunities offered } \\
\text { by Islamic banking system }\end{array}$ & 13 & 22 \\
\hline Salary account & 03 & 5.1 \\
\hline Total & 59 & 100 \\
\hline
\end{tabular}

Source: Calculated from primary data

\section{Respondents Perception at Different Aspects of Islamic Bank}

Customer perception is a vital factor. It differs from customer to customer. In this study, customer observation at different aspects of Islamic bank is analyzed in Likert-scale. A mean value greater than 2.50 indicates the respondents are in the range of Neutral to strongly agree. Smaller Standard Deviation (SD) shows lower dispersion among the responses to each statement.

From the table 6, it shows that above half of the respondents (69) agree with the statement that they are aware of Islamic banking products, services and finance. 21 participants are strongly agreed, and 20 are neutral with it. The mean value of 3.80 and Standard Deviation of 0.92 indicate that maximum respondents know about the products and services that differentiate Islamic bank from the conventional bank.

Account opening is the initial step to the bank-customer relationship. Bank must make the procedure simple and trouble-free. 59 respondents agree and 30 strongly agree with the statement "The process to open an account with the bank was easy." The mean value of 3.89 and Standard Deviation of 0.90 also prove that account opening system of Islamic bank is simple.

43 respondents don't have any opinion regarding the statement "Islamic Bank offers competitive service charges than conventional bank" whereas 41 agree and 15 strongly agree with the declaration. But 12 customers disagree, and nine strongly oppose it. Here the mean value and Standard Deviation is 3.33 and 1.06 respectively.

Profit or interest rate is an important determinant for choosing bank by the customer. Islamic Bank offers a competitive rate of profit than the conventional bank- 53 agrees, 18 disagree and 13 customers strongly agree with the statement while 33 are neutral regarding it. The mean value of 3.48 and Standard Deviation of 0.94 represent it.

A maximum number of participants (56) agree, and 14 disagree with the statement that Islamic banks offer more benefits/products than conventional banks. A significant number of respondents (39) neither agree nor disagree with it. The mean value is 3.43 , and Standard Deviation is 0.89 of this statement.

Islamic bank's ATM booth number and the location are sufficient- 38 customers are neutral with this statement and 35 are agreed while 27 disagree with it. Here the mean value is 3.03, and Standard Deviation is 1.10.

50 participants are agreed, and 35 strongly agree with the statement that information on certain Islamic banking products on leaflets/ brochures/websites is sufficient and can be easily understood. The mean value of 3.88 and Standard Deviation of 1.00 also support it. 
Table 6: Respondents Perception at different aspects of Islamic bank

\begin{tabular}{|c|c|c|c|c|c|c|c|}
\hline Statements & \begin{tabular}{|c|} 
Strongly \\
Disagree (1)
\end{tabular} & $\begin{array}{c}\text { Disagree } \\
(2)\end{array}$ & \begin{tabular}{|c|} 
Neither agree nor \\
Disagree (3)
\end{tabular} & $\begin{array}{c}\text { Agree } \\
(4)\end{array}$ & $\begin{array}{l}\text { Strongly } \\
\text { agree (5) }\end{array}$ & Mean & SD \\
\hline $\begin{array}{l}\text { 1. You are aware about Islamic banking products, } \\
\text { services and finance which are different from } \\
\text { conventional banks. }\end{array}$ & 05 & 05 & 20 & 69 & 21 & 3.80 & 0.92 \\
\hline $\begin{array}{l}\text { 2. The procedure to open an account with the bank } \\
\text { was easy. }\end{array}$ & 01 & 09 & 21 & 59 & 30 & 3.89 & 0.90 \\
\hline $\begin{array}{l}\text { 3. Islamic bank offers competitive service charges than } \\
\text { conventional bank. }\end{array}$ & 09 & 12 & 43 & 41 & 15 & 3.33 & 1.06 \\
\hline $\begin{array}{l}\text { 4. Islamic bank offers competitive rate of profit than } \\
\text { conventional bank. }\end{array}$ & 03 & 18 & 33 & 53 & 13 & 3.48 & 0.94 \\
\hline $\begin{array}{l}\text { 5. Islamic banks offer more benefits/ products than } \\
\text { conventional banks. }\end{array}$ & 03 & 14 & 39 & 56 & 08 & 3.43 & 0.89 \\
\hline $\begin{array}{l}\text { 6. Islamic bank's ATM booth number and location is } \\
\text { sufficient. }\end{array}$ & 11 & 27 & 38 & 35 & 09 & 3.03 & 1.10 \\
\hline $\begin{array}{l}\text { 7. Information on certain Islamic banking products on } \\
\text { leaflets / brochures / websites is sufficient and can be } \\
\text { easily understood. }\end{array}$ & 04 & 06 & 25 & 50 & 35 & 3.88 & 1.00 \\
\hline 8. Internet banking service of this bank is smooth. & 06 & 08 & 27 & 62 & 17 & 3.63 & 0.98 \\
\hline $\begin{array}{l}\text { 9. This bank's employee is highly professional, } \\
\text { skillful/efficient, and their attitude is excellent. }\end{array}$ & 02 & 09 & 29 & 46 & 34 & 3.85 & 0.98 \\
\hline $\begin{array}{l}\text { 10. Islamic banks follow the rules of Shariah /Sharia'h } \\
\text { Supervisory Board Committee. }\end{array}$ & 02 & 05 & 37 & 53 & 23 & 3.75 & 0.87 \\
\hline $\begin{array}{l}\text { 11. Terms and conditions set by the Islamic banks are } \\
\text { convenient. }\end{array}$ & 02 & 07 & 47 & 55 & 09 & 3.53 & 0.79 \\
\hline $\begin{array}{l}\text { 12. Quality \& Timeliness of complaint resolution in } \\
\text { Islamic bank is outstanding. }\end{array}$ & 07 & 14 & 35 & 51 & 13 & 3.42 & 1.02 \\
\hline $\begin{array}{l}\text { 13. You always get timely/prompt \& efficient service } \\
\text { whenever you visit the branch }\end{array}$ & 06 & 12 & 42 & 47 & 13 & 3.40 & 0.90 \\
\hline $\begin{array}{l}\text { 14. Quick Service and speed of transaction by Islamic } \\
\text { banks is satisfactory }\end{array}$ & 05 & 15 & 30 & 55 & 15 & 3.49 & 0.99 \\
\hline 15. They offer a wide range of facilities. & 01 & 16 & 39 & 56 & 08 & 3.49 & 0.85 \\
\hline 16. Your bank caters all your banking needs. & 01 & 12 & 50 & 43 & 14 & 3.52 & 0.84 \\
\hline $\begin{array}{l}\text { 17. You are satisfied with the overall service quality } \\
\text { provided by the bank. }\end{array}$ & 01 & 08 & 27 & 57 & 27 & 3.88 & 0.86 \\
\hline
\end{tabular}

Source: Calculated from primary data

Online banking is a vital factor in today's technology based world. 62 respondents are agreed, and 17 strongly agree that internet banking services of Islamic bank are smooth. But six customers strongly disagree with it. The mean value is 3.63, and Standard Deviation is 0.98 of this statement.

A significant number of respondents agree (46) and strongly agree (34) with the declaration Islamic bank's employee is highly professional, skillful/efficient, and their attitude is excellent. The mean value of 3.85 and Standard Deviation of 0.98 stand for it.

53 respondents agree, and 23 strongly agree that Islamic banks follow the rules of Shariah /Shariah Supervisory Board Committee. 37 customers are in a neutral position. Here the mean value is 3.75 , and Standard Deviation is 0.87 .

Large portions of the participant (47) are neither agreed nor disagreed with the statement- terms and conditions set by the Islamic banks are convenient. But 55 customers are agreed with it. The mean value is 3.53 , and Standard Deviation is 0.79 .

In response to the statement "quality \& timeliness of complaint resolution in Islamic bank is outstanding", 51 respondents agree, and 13 strongly agree with it. 35 respondents are neutral. Here the mean value is 3.42 , and Standard Deviation is 1.02 .

You always get timely/prompt \& efficient service whenever you visit the branch- 47 respondents agreed, and 42 are neutral. 13 strongly agree, and 12 disagree with it. The mean value is 3.40, and Standard Deviation is 0.90 of this statement.

Almost half of the respondents (55) agree, and 15 strongly agree with the statement-quick Service and speed of transaction by Islamic banks is satisfactory. Another 15 customers disagree, and 30 are neutral in reply to it. The mean value is 3.49 , and Standard Deviation is 0.99 . 
They offer a wide range of facilities- 56 participants are agreed, and 39 neither agree nor disagree with the statement. 16 customers disagree with it. Here the mean value is 3.49, and Standard Deviation is 0.85.

Maximum numbers of the participant (50) are neutral, and 43 contributors agree that Islamic bank caters all their banking needs. Here 14 customers strongly agree, and 12 respondents disagree with it. The mean value is 3.52 , and Standard Deviation is 0.84 of this statement.

57 respondents agreed, and 27 strongly agreed that they are satisfied with the overall service quality provided by the bank. But 27 customers are neutral to this statement. The mean value of 3.88 and Standard Deviation of 0.86 maintain it.

\section{CONCLUSION}

Customer perception is a vital factor for the banking sector. If customers have excellent opinion about a bank, it will increase the customers' reliability. Islamic bank's customer increases day by day. Experts predicting that the Islamic banking industry will continue in steady steps to become the mainstream banking system in Muslim South Asian nation. Bankers believe that the Islamic banking can achieve more progress if a law governing Islamic Banking policies could be introduced. The main purpose of the study is to find out customers' perception on different aspects of the Islamic bank. The findings of the research will help the concerned authority to increase their service quality, and remove their lacking.

Based on the response of the participants, for the betterment of service quality, the following strategies are recommended-

- Customer awareness is very much essential because it makes the customers remain loyal to the organization. Islamic bank should improve their advertisement for increasing awareness of clients about their product, services, and benefits they offer to their consumers.

- In Bangladesh, the Arabic terms of Islamic bank's product can't be easily understood by the client. To make customer familiar with such products, Islamic bank can try to find out some easier way.

- Islamic bank should increase ATM booths at the different central location. Also, they have to ensure smooth functioning of ATM booth and availability of money at the booth.

- A large number of customers of Islamic bank are from countryside areas. Many of the customers suggest opening branches in rural areas so that they can get services easily.

- Islamic bank those don't have satisfactory internet banking services, should ensure smooth internet banking services and increase internet banking facilities.
- Islamic bank should provide friendly and faster customer services though some customers complain about it.

- Many customers complain that Islamic bank provides dissatisfactory profit rate against the deposit. To ensure customer reliability, they should offer a competitive rate of profit against the different deposit.

\section{RefERENCES}

Abduh, M., Kassim, S., Dahari, Z. (2012), “Customer Satisfaction and Switching Behavior in Islamic Banking: Evidence from Indonesia", School of Doctoral Studies (European Union) Journal, pp. 209-215, retrieved fromhttp:/ / www.iiuedu.eu/press/journals/sds/SDS2012/SSc_Article7.pdf. [Accessed: 14th March 2016]

Ahmad, F., "Islamic Banking Blooms in Bangladesh", March 16, 2010, http://islamicbanking.info/islamic-banking-inbangladesh/. [Accessed: 14th February 2016]

Ahsan, M. (2016). Measuring Financial Performance Based on CAMEL: A Study on Selected Islamic Banks in Bangladesh. Asian Business Review, 6(1), 47-56.

Akbar, C. S., "Islamic Banking: History and development", The Financial Express, vol. 22 no. 138, March 31, 2015, available at http://print.thefinancialexpress-bd.com/2015/03/31/ 86909. [Accessed: 14th February 2016]

Akhtar, M. N., Hunjra, A. I., Akbar, S. W., Rehman, K. U., and Niazi, G. S. K. (2011)"Relationship Between Customer Satisfaction and Service Quality of Islamic Banks", World Applied Sciences Journal, vol. 13, no. 3, pp. 453-459.

Bashir, M. S. (2013), "Analysis of Customer Satisfaction with the Islamic Banking Sector: Case of Brunei Darussalam", Asian Journal of Business and Management Sciences, vol. 2 no. 10, pp. 38-50, retrieved fromhttps://www.researchgate.net/publication/236839121_A nalysis_of_Customer_Satisfaction_with_the_Islamic_Banki ng_Sector_Case_of_Brunei_Darussalam. [Accessed: 14th March 2016]

Begum, S., "A Comparative Study of Customer Satisfaction of Islamic Banks and Conventional Banks in Oman" The SIJ Transactions on Industrial, Financial \& Business Management (IFBM), vol. 2, no. 4, pp. 207-211Jun. 2014, retrieved fromhttp:/ / www.thesij.com/papers/IFBM/2014/June/IFBM0204480101.pdf. [Accessed: 14th March 2016]

Hassan, M. T., Ahmed, B., Ahmed, S., Habib, U., Riaz, S., Maqbool, N., and Anwar, A. (2012), "Measuring Customers Loyalty of Islamic Banking in Bahawalpur Region", International Journal of Learning $\mathcal{E}$ Development, vol. 2, no. 2, pp. 101-111.

Khan, M. M., and Fasih, M. (2014), "Impact of Service Quality on Customer Satisfaction and Customer Loyalty: Evidence from Banking Sector", Pakistan Journal of Commerce and Social Sciences, vol. 8 no. 2, pp. 331- 354.

Khan, M. S. N., Hassan, M. K., Shahid, A. I. (2007), "Banking Behavior of Islamic Bank Customers in Bangladesh", Journal of Islamic Economics, Banking, and Finance, pp. 159194, retrieved fromhttps://www.researchgate.net/publication/265427492_Ba nking_Behavior_of_Islamic_Bank_Customers_in_Banglade sh. [Accessed: 14th March 2016] 
Khan, M., and Ahmad, S., "Customer Satisfaction Level of Islamic Bank and Conventional Bank in Pakistan", IOSR Journal of Business and Management (IOSR-JBM), vol. 11, no. 1, pp 31-40, May - Jun. 2013.

Khattak, N. A., and Rehman, K. U., "Customer satisfaction and awareness of Islamic Banking system in Pakistan", African Journal of Business Management, vol. 4, no. 5, pp. 662-671, May 2010.

Mohammad, N., \& Kamal, S. (2016). Social Impact and Sustainability of Corporate Social Responsibility in the Banking Sectors: Bangladesh Perspective. Asian Business Review, 6(1), 39-46.

Nadia, S., Sonia, M., and Jaleleddine, B. R., "Ethical Performance of Islamic Banks: the Case of the Tunisian Banking "Zaytuna" Journal of Islamic Banking and Finance", Journal of Islamic Banking and Finance, vol. 2, no. 1, pp. 107-122, Mar. 2014, retrieved fromhttp://jibfnet.com/journals/jibf/Vol_2_No_1_March_201 4/7.pdf. [Accessed: 14th March 2016]
Naser, K., and Moutinho, L. (1997), "Strategic Marketing Management: the Case of Islamic Banks", International Journal of Bank Marketing, vol. 15, no. 6, pp. 187-203.

Naser, K., Salem, A. A., and Nuseibeh, R., "Customers Awareness and Satisfaction of Islamic Banking Products and Services: Evidence from the Kuwait Finance House", International Journal of Marketing Studies, Vol. 5, No. 6, pp. 185-199, Nov. 2013, retrieved fromhttp://connection.ebscohost.com/c/articles/93326651/cu stomers-awareness-satisfaction-islamic-banking-productsservices-evidence-from-kuwait-finance-house-note-1. [Accessed: 14th March 2016]

Yousuf, S., Islam, M. A., Islam, M. R., "Islamic Banking Scenario of Bangladesh", Journal of Islamic Banking and Finance, vol. 2, no. 1, pp. 23-29, Mar. 2014.

Online ISSN: 2305-8730

\section{Indexed Archive Links}

OCLC WorldCat: http://goo.gl/vhQzla

Google Scholar: https://goo.gl/t23FeQ

abcGATE: http://goo.gl/E6WdgA

BASE: http://goo.gl/sEd0SZ

\section{S. WorrldCat Google scholar abcGATE \BASE}

